\title{
Pendidikan/Penyuluhan Kesehatan tentang PHBS Tatanan Rumah Tangga
}

\author{
Iwan Shalahuddin, Udin Rosidin , Furkon Nurhakim \\ Dosen Fakultas Keperawatan Unpad Kampus Garut \\ Email: shalahuddin@unpad.ac.id
}

\begin{abstract}
Abstraks
Perilaku hidup bersih dan sehat (PHBS) adalah semua perilaku kesehatan yang dilakukan atas kesadaran sehingga anggota keluarga atau keluarga dapat menolong dirinya sendiri di bidang kesehatan, dan berperan aktif dalam kegiatan-kegiatan kesehatan di masyarakat. Salah satu sasaran PHBS adalah tatanan rumah tangga, maka melakukan asuhan dengan menerapkan strategi promkes pada tatanan rumah tangga.Penerapan PHBS di rumah tangga merupakan salah satu upaya strategis untuk menggerakan dan memberdayakan keluarga atau anggota rumah tangga untuk berprilaku PHBS. Tujuanya untuk memberdayakan setiap keluarga atau anggota rumah tangga agar tahu, mau, dan mampu menolong diri sendiri di bidang kesehatan dengan mengupayakan lingkungan yang sehat, mencegah dan menanggulangi masalah-masalah kesehatan yang dihadapi, memanfaatkan sarana pelayanan kesehatan yang ada, serta berperan aktif mewujudkan kesehatan masyarakatnya dan mengembangkan upaya kesehatan dan mengembangkan upaya kesehatan bersumber daya masyarakat. Hasil penyuluhan adanya peningkatan pengetahuan warga masyarakat tentang PHBS tatanan rumah tangga yaitu dari $40 \%$ warga yang memahami sebelum penyuluhan menjadi $90 \%$ warga memahaminya. Berdasarkan kondisi tersebut, perlu adanya strategi khusus untuk meningkatkan kesadaran dan perilaku warga dalam melaksanakan PHBS tatanan rumah tangga yang diawali dari keluarga.
\end{abstract}

Kata kunci: PHBS, tatanan rumah tangga, warga masyarakat, pengetahuan.

\begin{abstract}
Clean and healthy behavior (PHBS) is all health behaviors carried out on awareness so that family members or families can help themselves in the health sector, and play an active role in health activities in the community. One of the targets of PHBS is the household arrangement, then caring for it by applying the promkes strategy on the household order. The application of PHBS in the household is one of the strategic efforts to mobilize and empower families or household members to behave in PHBS. The aim is to empower every family or household member to know, want and be able to help themselves in the health sector by seeking a healthy environment, preventing and overcoming health problems faced, utilizing existing health care facilities, and playing an active role in creating health. the community and develop health efforts and develop community-based health efforts. The result of counseling was an increase in the knowledge of the community about PHBS in the household structure, namely from $40 \%$ of the residents who understood before the extension became $90 \%$ of the residents understood it. Based on these conditions, it is necessary to have a specific strategy to increase the awareness and behavior of citizens in implementing PHBS household arrangements that start from the family.
\end{abstract}

Keywords: Communit, household, knowledge, PHBS. 


\section{Pendahuluan}

Kebijakan Indonesia Sehat menetapkan tiga pilar utama yaitu lingkungan sehat, perilaku sehat dan pelayanan kesehatan bermutu adil dan merata. Untuk mendukung pencapaian visi Indonesia Sehat telah ditetapkan Sistem Kesehatan Nasional (SKN) dengan Keputusan Menteri Kesehatan No.131/Menkes/SK/II/2004 dan salah satu subsistem dari SKN adalah subsistem Pemberdayaan Masyarakat. Kebijakan Nasional Promosi Kesehatan (Promkes) untuk mendukung upaya peningkatan perilaku sehat ditetapkan visi nasional Promkes sesuai Keputusan Menteri Kesehatan RI. No.1193/MENKES/SK/X/2004 yaitu Perilaku Hidup Bersih dan Sehat 2010 (PHBS 2010).

Untuk melaksanakan program Promkes di daerah telah ditetapkan Pedoman Pelaksanaan Promkes di daerah dengan Keputusan Menteri Kesehatan RI. No.1114/Menkes/SK/VIII/2005. Tujuan Promkes yaitu mewujudkan derajat kesehatan masyarakat setinggi-tingginya yang ditandai oleh penduduk yang hidup dengan perilaku hidup bersih dan sehat dalam lingkungan yang sehat.

Ruang lingkup Promkes di Puskesmas, pembinaan Usaha Kesehatan Berbasis Masyarakat (UKBM), pelaksanaan penyuluhan (dalam dan luar gedung), dan Perilaku Hidup Bersih dan Sehat (PHBS) (Hati, S. 2008). Peran serta Puskesmas yang bertanggung jawab menyelenggarakan pembangunan kesehatan khususnya tentang PHBS di wilayah kerja belum tampak atau masih kurang (Artini, N. N. 2010).

Pembangunan kesehatan bertujuan meningkatkan kesadaran, kemampuan dan kemauan hidup sehat bagi setiap penduduk agar dapat mewujudkan derajat kesehatan yang setinggi-tingginya. (Indonesia, R. 2009). Masyarakat diharapkan mampu berperan sebagai pelaku pembangunan kesehatan dalam menjaga, memelihara dan meningkatkan derajat kesehatannya sendiri serta berperan aktif dalam mewujudkan kesehatan masyarakat.

Harapan tersebut dapat terwujud apabila masyarakat diberdayakan sepenuhnya dengan sumber daya dimilikinya untuk dapat menerapkan PHBS dalam kehidupannya sehari-hari, baik di rumah, di sekolah, di tempat kerja.

Perilaku Hidup Bersih dan Sehat (PHBS) yang harus dilakukan oleh setiap individu/keluarga/kelompok sangat banyak, dimulai dari bangun tidur sampai dengan tidur kembali. Perilaku Hidup Bersih dan Sehat adalah sekumpulan perilaku yang dipraktekkan atas dasar kesadaran sebagai hasil pembelajaran yang menjadikan individu/keluarga/kelompok dapat menolong dirinya sendiri dalam bidang kesehatan dan berperan aktif dalam mewujudkan derajat kesehatan masyarakat.

Salah satu sasaran PHBS adalah tatanan rumah tangga, maka kelompok melakukan asuhan dengan menerapkan strategi promkes pada tatanan rumah tangga.Penerapan PHBS di rumah tangga merupakan salah satu upaya strategis untuk menggerakan dan memberdayakan keluarga atau anggota rumah tangga untuk berprilaku PHBS. PHBS dirumah tangga di arahkan untuk memberdayakan setiap keluarga atau anggota rumah tangga agar tahu, mau, dan mampu menolong diri sendiri di bidang kesehatan dengan mengupayakan lingkungan yang sehat, mencegah dan menanggulangi masalah- 
Iwan Shalahuddin : Pendidikan/Penyuluhan Kesehatan tentang PHBS Tatanan Rumah Tangga

masalah kesehatan yang dihadapi, memanfaatkan sarana pelayanan kesehatan yang ada, serta berperan aktif mewujudkan kesehatan masyarakatnya dan mengembangkan upaya kesehatan dan mengembangkan upaya kesehatan bersumber daya masyarakat. Oleh karena itu kegiatan PHBS dirumah tangga pelaksanaannya dimulai dari lingkungan terkecil, yaitu RT, RW, Dusun, kampung, Desa/Kelurahan.

Perilaku hidup bersih dan sehat (PHBS) adalah semua perilaku kesehatan yang dilakukan atas kesadaran sehingga anggota keluarga atau keluarga dapat menolong dirinya sendiri di bidang kesehatan, dan berperan aktif dalam kegiatan-kegiatan kesehatan di masyarakat. Dalam PHBS juga dilakukan edukasi untuk meningkatkan pengetahuan, sikap dan perilaku melalui pendekatan pimpinan (advocacy), bina suasana (social support) dan pemberdayaan masyarakat (empowerment). (Proverawati, A., \& Rahmawati, E. 2012).

PHBS pada tatanan rumah tangga adalah upaya untuk memberdayakan anggota rumah tangga agar sadar, mau dan mampu melakukan PHBS untuk memelihara dan meningkatkan kesehatannya, mencegah risiko terjadinya penyakit dan melindungi diri dari ancaman penyakit serta berperan aktif dalam gerakan kesehatan di masyarakat (Irawati, E. 2011).

Persoalan yang mengemuka dari beberapa ruang lingkup kegiatan Promkes yang telah ditetapkan oleh Depkes. PHBS merupakan salah satu ruang lingkup dari Promkes selalu dilupakan. Akibatnya, program PHBS tidak sesuai dengan yang diharapkan oleh pemerintah. Sistem penilaian terhadap PHBS rumah tangga yang digunakan saat ini adalah rumah tangga yang menerapkan PHBS dan rumah tangga yang tidak menerapkan PHBS. Suatu rumah tangga sudah dikatakan tidak menerapkan PHBS jika salah satu indikator PHBS rumah tangga tidak terpenuhi. PHBS tatanan rumah tangga penting dilakukan untuk meningkatkan kesehatan keluarga. Ini bertujuan agar anak dapat tumbuh dengan sehat dan cerdas. Di samping itu, kemampuan bekerja setiap anggota keluarga meningkat, serta pengeluaran biaya rumah tangga dapat digunakan untuk pemenuhan gizi keluarga, pendidikan, dan peningkatan pendapatan. Bagi masyarakat, akan tercipta lingkungan yang sehat dan mampu mencegah serta menanggulangi masalah-masalah kesehatan. Rumah tangga sehat merupakan aset dan modal utama pembangunan di masa depan. Kesakitan dan kematian karena penyakit infeksi dan non infeksi dapat dicegah dengan berperilaku hidup bersih dan sehat.

Berdasarkan latar belakang di atas, untuk meminimalisasi terjadinya dan dampak dari tidak menerapkan PHBS tatanan rumah tangga, perlu diberikan arahan dan pendidikan ilmu pengetahuan yang berkelanjutan, salah satunya dengan penyuluhan/pendidikan kesehatan tentang PHBS diawali dari tingkat rumah tangga yang berada diwilayah RT, RW dan secara luasnya di wilayah desa dengan harapan masyarakat mampu melakukan pola hidup sehat sesuai indikator yang telah di tentukan, masyarakat mampu meningkatkan tinggat kesadaran dan kesehatan masyarakat akan pentingnya kesehatan, sehingga secara tidak langsung tingkat kesehatan masyarakat akan meningkat. 


\section{Metode}

Metode Yang Digunakan Dalam Kegiatan Pengabdian pada masyarakat ini adalah dengan pendidikan kesehatan pada masyarakat dam bentuk ceramah, tanya jawab dan diskusi. Masyarakat yang hadir terdiri dari ibu-ibu dan bapak-bapak yang berasal dari RT 01 dan 02 RW 09 Desa Jayaraga berjumlah 120 orang. Sebelum dilakukan penyuluhan, terlebih dahulu menanyakan pemahaman masyarakat mengenai PHBS tatanan rumah tangga. Penyuluhan dilaksanakan di mesjid Nurul Islam RT 01 RW 09 desa jayaraga dengan durasi satu jam dimana 20 menit pemaparan materi dan 30 menit 40 menit untuk diskusi bagi masyarakat yang ingin mengajukan pertanyaan. Kemudian dilakukan evaluasi singkat dengan mengajukan pertanyaan kepada masyarakat. Rincian materi yang disampaikan adalah Definisi PHBS, definisi PHBS tatanan rumah tangga dan indikator PHBS tatanan rumah tangga.

\section{Hasil}

Persiapan Administrasi dimulai dengan Melakukan koordinasi ke lokasi sasaran yaitu Masyarakat RT 1 dan 2 RW 09 Desa Jayaraga, untuk memberitahukan rencana kegiatan yang akan dilakukan dan berkonsultasi untuk menentukan hari, tempat dan sasaran penyuluhan. Koordinasi di masyarakat di terima langsung oleh ketua RW dan Ketua RT dengan hasil menentukan tentang pelaksanaan kegiatan tersebut, yaitu pada: Hari

Kamis tanggal 26 Oktober 2017, jam 16.00 sampai selesai bertempat di mesjid Nurul Islam.

Pelaksanaan acara dipimpin langsung oleh ketua DKM mesjid Nurul Islam sekaligus membuka dan memberikan sambutan sebagai tokoh agama yang mewakili ketua RW 09 desa Jayaraga dengan isi sambutan menekankan pentingnya memahami PHBS di tatanan rumah tangga dengan harapat kedepannya msayarakat Rw 09 dapat melakukan dan melaksanakan PHBS tatanan rumah tangga agar terhindar dari berbagai maslah kesehatan warganya.

Selanjtnya dilakukan tanya jawab oleh pemberi materi untuk menggali sejauh mana pengetahuan dan pemahaman warga masyarakat mengenai PHBS tatanan rumah tangga dengan memberikan pertanyaan secara lisan. Hasil yang didapatkan menunjukan bahwa warga masyarakat sekitar $40 \%$ dapat menjawab dan memahami tentang materi tersebut. Kegiatan dilanjutkan dengan pemaparan materi selama 15-20 menit menyampaikan secara garis besar tentang pengertian PHBS, pengertian PHBS tatanan rumah tangga dan indikator PHBS tatanan rumah tangga yang dapat dilakukan secara mudah dan sederhana oleh warga masyarakat. Selain itu pemberi materi juga menampilkan contoh-contoh gambar tentang pelaksanaan PHBS tatanan rumah tangga.

Setelah dilakukan pemberian materi dan meyajikan contoh nyata tentang gambar-gambar, warga masyarakat diberi kesempatan untuk bertanya mengenai PHBS tatanan rumah tangga dan dilanjutkan dengan pertanyaan dari pemberi materi. Hasil evaluasi menunjukan bahwa warga masyarakat begitu antusias terhadap materi penyuluhan terutama menyoroti tentang perilaku meroko di rumah, tidak ada peserta yang meninggalkan tempat penyuluhan sebelum acara berakhir, warga 
Iwan Shalahuddin : Pendidikan/Penyuluhan Kesehatan tentang PHBS Tatanan Rumah Tangga

mengajukan beberapa pertanyaan dan hampir seluruhnya warga (90\%) dapat menjawabnya dengan benar.

\section{Pembahasan}

Dari berbagai faktor dan permasalahan yang terjadi di warga masyarakat tentang pelaksanaan PHBS tatanan rumah tangga selalu terbentur dengan permasalahan pemahaman tentang aplikasi dari PHBS tersebut, sehingga sangat dibutuhkan peningkatan pengetahuan dan pemahaman agar dapat merubah sikap dan perilaku warga dalam menciptakan suasana rumah tangga yang sehat. Sesuai dengan hasil penelitian Damaiyanti, S., \& Hardyanti, C. (2015). yang menunjukan bahwa responden yang memiliki pengetahuan tinggi didapatkan Ibu Rumah Tangga menerapkan PHBS $(5,9 \%)$ Ibu Rumah Tangga yang tidak menerapkan PHBS, sedangkan responden yang memiliki pengetahuan rendah (14,3\%) Ibu Rumah Tangga menerapkan PHBS dan (85,7\%) Ibu Rumah Tangga tidak menerapkan PHBS.

Pengetahuan merupakan hasil dari tahu, dan ini terjadi setelah orang melakukan pengindraan terhadap suatu objek tertentu. Pengindraan terjadi melalui pancaindra manusia, yakni indra penglihatan, pendengaran, penciuman, rasa, dan raba. Sebagian besar pengetahuan manusia diperoleh melalui matadan telinga. Pengetahuan atau ranah kognitif merupakan domain yang sangat penting dalam membentuk tindakan seseorang (Notoatmodjo 2012).

Menurut Rogers didalam Notoatmodjo 2007, untuk mengadakan suatu perubahan perlu ada beberapa langkah yang ditempuh sehingga harapan atau tujuan akhir dari perubahan dapat tercapai. Pengetahuan juga dipengaruhi oleh beberapa faktor, diantaranya faktor internal seperti pendidikan, pekerjaan, umur sedangkan faktor eksternal seperti faktor lingkungan dan sosial budaya (Wawan dan Dewi 2011).

Menurut pemateri pengetahuan rendah responden dikarenakan kurang terpaparnya masyarakat tentang informasi kesehatan, khususnya pengetahuan PHBS. Berdasarkan penelitian yang dilakukan, banyak masyarakat yang belum tahu informasi PHBS, baik definisi PHBS itu sendiri maupun indikator-indikator yang terdapat dalam PHBS. Kurangnya pengetahuan masyarakat juga di sebabkan oleh pendidikan, karena pendidikan yang rendah masyarakat tidak begitu mengerti tentang program PHBS. Pekerjaan, lingkungan dan sosial budaya juga mempengaruhinya karena masyarakat kebanyakan adalah pedagang. Menurut pemateri rendahnya penerapan PHBS di RW 09 Desa Jayaraga disebabkan indikator PHBS sangat berat untuk diterapkan dirumah tangga, karena untuk 10 indikator jika salah satu tidak dipenuhi maka rumah tangga itu dikatakan tidak menerapkan PHBS. Untuk indikator persalinan ditolong oleh tenaga kesehatan, hampir semua ibu telah melakukan persalinan oleh tenaga kesehatan. Ini menggambarkan bahwa anggota rumah tangga khususnya ibu hamil mengerti pentingnya persalinan ditolong oleh tenaga kesehatan.

Untuk indikator pelaksanaan pemberian ASI ekslusif, ibu telah memberikan ASI ekslusif untuk bayi usia 06 bulan. Namun masih ada sebagian ibu yang tidak memberikan ASI eksklusif. Hasil 
tersebut menggambarkan bahwa ibu masih kurang memahami manfaat pemberian ASI ekslusif, beberapa alasan diantaranya adalah tradisi budaya yang telah turun temurun bahwa anak akan cepat kenyang dan tidak akan menangis lagi jika diberikan makanan tambahan, dan hal ini akan mengganggu pertumbuhan dan perkembangan bayi. Selain itu daya tahan bayi terhadap penyakit lebih rendah, sehingga bayi akan mudah sakit dan menjadi kurang aktif.

Untuk indikator penimbangan bayi dan balita di posyandu menggambarkan bahwa ibu bayi atau balita tersebut tahu dan mengerti bahwa menimbang bayi atau balita penting untuk mengontrol berat badan bayi atau balita mereka. Agar nantinya tidak ada bayi atau balita yang memiliki penyakit obesitas atau kekurangan gizi.

Untuk indikator penggunaan air bersih, ibu sudah menggunakan air bersih. Ini menggambarkan bahwa ada beberapa ibu rumah tangga (keluarga) belum mengerti pentingnya penggunaan air bersih dalam aktivitas sehari-hari. Padahal jika anggota rumah tangga masih menggunakan air yang tidak bersih untuk mencuci, untuk mandi, atau bahkan untuk minum, hal tersebut akan membahayakan anggota rumah tangga tersebut. Sedangkan untuk ibu rumah tangga yang sudah menggunakan air bersih, sebaiknya hal ini dipertahankan agar penyakit yang timbul akibat tidak menggunakan air bersih dapat berkurang bahkan bisa dihindari.

Untuk indikator penggunaan air bersih dan sabun untuk mencuci tangan, ibu rumah tangga sudah menggunakan air bersih dan sabun. Namun ada juga diantara ibu yang tidak mencuci tangan dengan air bersih. Hasil tersebut menggambarkan bahwa ada beberapa anggota rumah tangga belum mengerti pentingnya penggunaan air bersih dan penggunaan sabun dalam mencuci tangan. Padahal jika anggota rumah tangga tidak menggunakan sabun untuk mencuci tangan hal tersebut akan membahayakan anggota rumah tangga tersebut. Penyakit tidak dapat dihindari, terlebih jika sebelum makan dan setelah BAB tidak menggunakan air bersih dan sabun.

Mengenai penggunaan jamban sehat, masih ada warga yang rumah tangga belum menggunakan jamban sehat. Ini menggambarkan bahwa ada rumah tangga yang belum mengerti pentingnya penggunaan jamban sehat. Padahal jika anggota rumah tangga masih memilih menggunakan sungai untuk $\mathrm{BAB}$ akan membahayakan lingkungan sekitar.

Untuk indikator pemberantasan jentik nyamuk, ibu rumah tangga telah sadar untuk memberantas jentik nyamuk. Nyamuk yang akhir-akhir ini menimbulkan banyak masalah, akan berakibat serius jika Ibu rumah tangga dan keluarga tidak memberantas jentik nyamuk. Penyakitpenyakit tersebut dapat dihindari atau diperkecil persentasenya jika pemberantasan jentik nyamuk rutin dilakukan oleh anggota rumah tangga khususnya.

Tentang konsumsi sayur dan buah setiap hari, ibu rumah tangga belum rutin mengonsumsi buah dan sayur setiap hari. Ini menggambarkan bahwa Ibu rumah tangga belum mengerti pentingnya konsumsi sayur dan buah untuk tubuh dalam kesehariannya. 
Iwan Shalahuddin : Pendidikan/Penyuluhan Kesehatan tentang PHBS Tatanan Rumah Tangga

Anggota rumah tangga yang melakukan aktivitas fisik setiap harinya begitu sedikit. Ini menunjukkan bahwa masyarakat kurang mengerti pentingnya olahraga atau aktivitas fisik setiap hari, baik aktivitas ringan, sedang, maupun berat. Setidaknya aktivitas fisik ini rutin dilakukan oleh anggota rumah tangga agar kesehatan anggota rumah tangga dapat terjaga.

Sedangkan untuk aktivitas merokok rumah tangga yang bebas asap rokok masih sedikit. Masih banyaknya masyarakat yang kurang sadar akan bahaya asap rokok terhadap anggota keluarga lainnya. Dari hasil diskusi menggambarkan masih lebih dari setengahnya yang anggota keluarganya melakukan kegiatan merokok . Ini sangat membahayakan anggota keluarga lain jika kegiatan merokok masih dilakukan di dalam rumah, karena rumah memiliki ruang-ruang terbatas sehingga asap dari rokok tidak akan keluar, terlebih lagi jika ada bayi dan balita di dalam rumah tersebut.

Terkait dengan hal tersebut diatas, perlu sosialisasi dari petugas kesehatan dan kesadaran dari masyarakat akan pentingnya penerapan perilaku hidup bersih dan sehat dalam rumah tangga. Jika tidak ada sosialisasi ataupun penyuluhan secara rutin, ada kemungkinan anggota rumah tangga semakin tak peduli dengan kesehatan dan bahaya dari asap rokok khusunya.

\section{Simpulan}

Warga masyarakat RW 09 Desa Jayaraga pada dasarnya sebagian besar pernah terpapar dengan informasi untuk melakukan perilaku hidup bersih dan sehat di tatanan rumah tangga, hanya indikatorindikatornya belum terlaksana secara keseluruhan terkait dengan berbagai macam faktor. Berdasarkan kondisi tersebut, perlu adanya strategi khusus untuk meningkatkan kesadaran dan perilaku warga dalam melaksanakan PHBS tatanan rumah tangga yang diawali dari keluarga.. Oleh karena itu, warga masyarakat RW 09 diberikan penyuluhan mengenai PHBS tatanan rumah tangga. Setelah mendapatkan pendidikan kesehatan ini, warga mampu mengetahui terkait PHBS tersebut.

\section{Ucapan Terima Kasih}

Penulis mengucapkan terima kasih kepada berbagai pihak yang telah membantu menyelesaikan kegiatan penyuluhan ini, antara lain kepala desa Jayaraga Garut, Ketua RW 09, Ketua RT 01 dan 02 yang selalu membantu dalam mempersiapkan rangkaian kegiatan ini, warga masyarakat yang telah bersedia menjadi peserta kegiatan ini, serta keluarga dan teman-teman yang telah membantu baik dari segi waktu dan tenaga sehingga penulis dapat menyelesaikan penyuluhan ini.

\section{Daftar Pustaka}

Artini, N. N. (2010). Hubungan pengetahuan dan sikap orang tua bayi dengan penerapan perilaku hidup bersih dan sehat di puskesmas Pasundan Samarinda Kalimantan Timur (Doctoral dissertation, Universitas Sebelas Maret).

Damaiyanti, S., \& Hardyanti, C. (2015). Hubungan Pengetahuan Ibu Rumah Tangga Dan Peran Kader Dengan Perilaku Hidup Bersih Dan Sehat (PHBS) Dalam Rumah Tangga Di Kelurahan Laing 
Wilayah Kerja Puskesmas Nan Balimo Kecamatan Tanjung Harapan Kota Solok Tahun 2014. 'AFIYAH, 2(1)

Dewi, Wawan. 2011. Teori Dan Pengukuran Pengrtahuan, Sikap Dan Perilaku Manusia. Nuha Medika : Yogyakarta.

Hati, S. (2008). Pengaruh Stategi Promosi Kesehatan Terhadap Tingkat Perilaku Hidup Bersih Dan Sehat (PHBS) Pada Tatanan Rumah Tangga DI Kecamatan Patumbak Kabupaten Deli Serdang (Master's thesis).

Indonesia, R. (2009). Undang-undang Republik Indonesia nomor 36 tahun 2009 tentang Kesehatan. Jakarta: Republik Indonesia

Irawati, E. (2011). Gambaran Karakteristik Keluarga Tentang Perilaku Hidup Bersih dan Sehat (PHBS) Pada Tatanan Rumah Tangga di Desa Karangasem Wilayah Kerja Puskesmas Tanon II Sragen. Gaster| Jurnal Ilmu Kesehatan, 8(2), 741-749

Irawati, E. (2011). Gambaran Karakteristik Keluarga Tentang Perilaku Hidup Bersih dan Sehat (PHBS) Pada Tatanan Rumah Tangga di Desa Karangasem Wilayah Kerja Puskesmas Tanon II Sragen. Gaster| Jurnal Ilmu Kesehatan, 8(2), 741-749.

Notoatmodjo, S. 2010. Ilmu Perilaku Kesehatan. PT Rineka Cipta Jakarta.

Proverawati, A., \& Rahmawati, E. (2012). Perilaku hidup bersih dan sehat (PHBS). Yogyakarta: Nuha Medika. 